\title{
The Influence of Isomerism on Crystallization in Aluminum Pyridinedicarboxylate Coordination Compounds
}

\author{
Michael T. Wharmby* ${ }^{[a, b]}$ and Norbert Stock ${ }^{[a]}$ \\ Dedicated to Professor Wolfgang Bensch on the Occasion of his 65th Birthday
}

Abstract. The reactions of three isomeric pyridinedicarboxylic acid linkers - 2,4-, 2,6-, and 3,5-pyridinedicarboxylic acid - with various aluminum salts were investigated by high-throughput solvothermal synthesis. Two coordination compounds were obtained from the symmetrical linkers (2,6- and 3,5-pyridinedicarboxylic acid). The former is based on molecular Al-O dimers, similar to those reported in the coordination polymer CAU-16. The latter forms a porous extended framework and is a member of the CAU-10 family of compounds. Full characterization of both compounds is reported. Crystal structures were determined from high-resolution synchrotron powder diffraction data. The number of guest water molecules determined crystallographically is in excellent agreement with the number found by thermogravimetric and elemental analyses. It was found that the CAU-10 analogue undergoes a reversible, displacive phase transition from a non-centrosymmetric to a centrosymmetric space group on loss of guest water molecules, due to guest-framework interactions.

\section{Introduction}

The application of metal-organic frameworks (MOFs) as water sorbents for de-/humidification and water production applications has grown in popularity in recent years. ${ }^{[1-3]}$ A precondition for such use is long term stability under operating conditions, which is usually investigated by repeated cycles of ad- and desorption under hydrothermal conditions. ${ }^{[4]}$ MOFs constructed from high-valence metals, such as $\mathrm{Zr}^{4+}$ or $\mathrm{Cr}^{3+}$, demonstrate good stability under these conditions, compared to the significantly larger number of MOFs reported with divalent metal cations. ${ }^{[5]}$ Among these higher valent compounds, a number of $\mathrm{Al}^{3+}$-based MOFs have demonstrated notably better stability and water sorption performances. Aluminum fumarate $\left[\mathrm{Al}(\mathrm{OH})\left(\mathrm{O}_{2} \mathrm{C}-\mathrm{C}_{2} \mathrm{H}_{2}-\mathrm{CO}_{2}\right)\right],{ }^{[6,7]}$ a structural analogue of the intensively studied compound MIL-53 (MIL = Materiaux Institut Lavoisier $)^{[8,9]}$ has been shown to withstand 4,500 water sorption cycles between 20 and $125^{\circ} \mathrm{C}$ at a relative humidity of ca. 55\%. The second example, aluminum isophthalate $\left[\mathrm{Al}(\mathrm{OH})\left(\mathrm{O}_{2} \mathrm{C}-\mathrm{C}_{6} \mathrm{H}_{4}-\mathrm{CO}_{2}\right)\right]$, also known as CAU-10 (CAU = Christian-Albrechts-Universität), ${ }^{[10]}$ has shown an even greater stability, achieving at least 10,000 water sorption cycles. ${ }^{[1]}$ Finally, a structural analogue of CAU-10, aluminum furandicarboxylate $\left[\mathrm{Al}(\mathrm{OH})\left(\mathrm{O}_{2} \mathrm{C}-\mathrm{C}_{4} \mathrm{H}_{2} \mathrm{O}-\mathrm{CO}_{2}\right)\right]$, known as MIL-160, has also shown promise for water sorption applications. ${ }^{[12,13]}$

* Dr. M. T. Wharmby

E-Mail: michael.wharmby@desy.de

[a] Institut für Anorganische Chemie

Christian-Albrechts-Universität zu Kiel

Max-Eyth-Str. 2

24118 Kiel, Germany

[b] Deutsches Elektronen-Synchrotron (DESY)

Notkestr. 85

22607 Hamburg, Germany

Supporting information for this article is available on the WWW under http://dx.doi.org/10.1002/zaac.201800353 or from the author.
It should be noted that all three of these compounds have a structural motif of unidirectional channels, deriving from the $\mu_{2}$-hydroxo corner-sharing chains, which are recognized as a chemically robust secondary building unit (SBU). ${ }^{[5]}$

A particular feature of the synthetic chemistry of MOFs is the ease with which compounds with the same network topology, but incorporating different SBUs may be prepared. The approach, referred to as either isoreticular synthesis ${ }^{[14]}$ or scale chemistry, ${ }^{[15]}$ has been widely applied to the replacement of ligands, for example in the case of DUT-4 or DUT-5, which both have MIL-53 structures, but where terephthalate is replaced by 2,6-napthalenedicarboxylate or 4,4'-biphenyldicarboxylate, respectively; ${ }^{[16]}$ and it has been applied to the partial or complete replacement of metal cations/clusters, as for example with $\mathrm{Zr}^{4+}$ and $\mathrm{Ce}^{4+}$ in the compounds $M^{\mathrm{IV}}$-terephalate UiO-66. ${ }^{[17]}$

During the initial characterization of CAU-10, the compound demonstrated a strong influence of the functional group on the sorption properties, ${ }^{[10]}$ and moreover was also found to show good stability against hydrolysis. The inclusion of an additional coordinating functional group might be expected to change the host-guest interactions or lead to a different synthetic pathway and hence a new product, thanks to different coordinative bonding possibilities. ${ }^{[18]}$ The isomeric organic molecules 2,4-pyridindedicarboxylic acid $\left(\mathrm{H}_{2} \mathbf{2}, \mathbf{4}\right.$ pydc), 2,6pyridinedicarboxylic acid $\left(\mathrm{H}_{2} \mathbf{2 , 6 p y d c}\right)$ and 3,5-pyridinedicarboxylic acid $\left(\mathrm{H}_{2} 3,5\right.$ pydc) all have the same meta-substitution pattern of the carboxylic acid groups relative to oneanother and are hence structural analogues of isophthalic acid, which is used in the synthesis of CAU-10 (Scheme 1). We also note that $\mathrm{H}_{2} \mathbf{2 , 6 p y d c}$ has an arrangement related to that of 2,4,6-pyridinetricarboxylic acid $\left(\mathrm{H}_{3}\right.$ PTC). On reaction with $\mathrm{Al}^{3+}, \mathrm{H}_{3}$ PTC forms first a molecular compound, $\left[\mathrm{Al}(\mu-\mathrm{OH})\left(\mathrm{H}_{2} \mathrm{O}\right)(\mathbf{P T C})\right]_{2}$, and subsequently a wine-rack chan- 
nel structure, labeled CAU-16 $\left(\left[\mathrm{Al}(\mu-\mathrm{OH})\left\{\mathrm{Al}(\mu-\mathrm{OH})\left(\mathrm{H}_{2} \mathrm{O}\right)\right.\right.\right.$ (PTC) $\left.\left.\}_{2}\right]\right)^{[19]}$ CAU-16 forms through coordination of $\mathrm{Al}^{3+}$ cations by the free carboxylate group of the molecular dimer, which is thought to be a structural intermediate.<smiles>O=C(O)c1ccnc(C(=O)O)c1</smiles>

$\mathrm{H}_{2} 2,4$ pydc<smiles>O=C(O)c1cccc(C(=O)O)n1</smiles>

$\mathrm{H}_{2} 2,6$ pydc<smiles>O=C(O)c1cncc(C(=O)O)c1</smiles>

$\mathrm{H}_{2} 3,5$ pydc
Scheme 1. The three isomeric pyridinedicarboxylic acid linkers investigated.

Herein we report a synthetic study of the complex-forming chemistry of three isomeric pyridinedicarboxylic acid linkers, determining the conditions necessary to obtain a pyridine functionalized form of CAU-10 (CAU-10-pydc). Whilst the water sorption properties of CAU-10-pydc have been reported previously, ${ }^{[12]}$ herein we present a full structural characterization of the compound and report a new dimeric Al-O cluster compound, closely related to CAU- 16 .

\section{Results and Discussion}

\section{Synthesis}

The reaction of $\mathrm{Al}^{3+}$ salts with three isomeric pyridine dicarboxylate linkers (Scheme 1) was investigated using an inhouse developed 24 reactor multiclave. ${ }^{[20]}$ Reactions of $\mathrm{H}_{2}$ 3,5pydc with six $\mathrm{Al}^{3+}$ salts $\left[\mathrm{AlCl}_{3}, \mathrm{Al}\left(\mathrm{NO}_{3}\right)_{3}, \mathrm{Al}(\mathrm{OH})_{3}\right.$, $\mathrm{Al}(\mathrm{OH})(\mathrm{AcO})_{2}, \mathrm{Al}_{2} \mathrm{O}_{3}$ and $\mathrm{Al}_{2}\left(\mathrm{SO}_{4}\right)_{3}$; full hydration states of all salts given in Experimental Section] in a DMF: $\mathrm{H}_{2} \mathrm{O}$ mixture (1:1) were first investigated. From $\mathrm{Al}\left(\mathrm{NO}_{3}\right)_{3}, \mathrm{AlCl}_{3}$, and $\mathrm{Al}_{2}\left(\mathrm{SO}_{4}\right)_{3}$, a highly crystalline bright yellow powder was obtained, labelled 1-AP and later found to be isostructural with the known compound CAU-10 (CAU-10-pydc; see Structural Analysis). The most crystalline product was obtained from $\mathrm{Al}\left(\mathrm{NO}_{3}\right)_{3}$. A subsequent high-throughput optimization array was used to determine the optimum stoichiometry and also the DMF: $\mathrm{H}_{2} \mathrm{O}$ solvent ratio (Figure 1). Finally, from these optimized conditions a series of reactions was performed at different temperatures $\left(80,120,140\right.$, and $\left.160^{\circ} \mathrm{C}\right)$ to determine the optimal reaction temperature. The final optimised reaction conditions of 1-AP were used in a scaled-up synthesis (see Experimental Section: Optimized scale-up synthesis of 1).

The yellow color of freshly prepared samples of $\mathbf{1 - A P}$ was found to fade over time, when the compound is left in air. This process can be accelerated by calcination at $250{ }^{\circ} \mathrm{C}$ in flowing nitrogen for $3 \mathrm{~h}$; the still crystalline compound, referred to as 1-H2O, has a pale cream color and absorbs water from the air on cooling (see Thermoanalytical Studies). This latter compound has been thoroughly characterized in this work.

With $\mathrm{H}_{2} 2$,4pydc and $\mathrm{H}_{2} 2$,6pydc, only high-throughput syntheses based around the optimized conditions of the discovery array used with $\mathrm{H}_{2} \mathbf{3 , 5 p y d c}$ were performed. A temperature of $120{ }^{\circ} \mathrm{C}$ and reaction time of $12 \mathrm{~h}$ was used for both of these reactions. With $\mathrm{H}_{2} \mathbf{2}$,6pydc, it was found that a phase, labeled 2, consisting of large, blocky, white crystals could be obtained

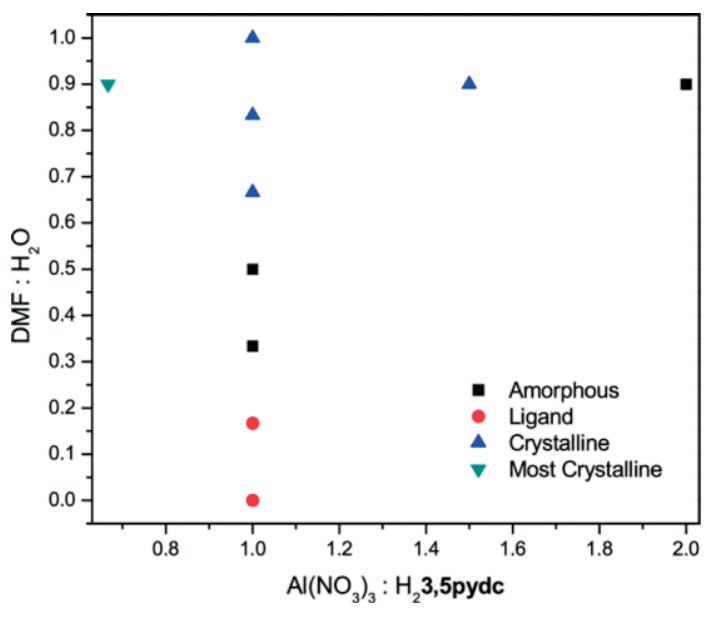

Figure 1. Plot showing the $\mathrm{Al}\left(\mathrm{NO}_{3}\right)_{3} \cdot 9 \mathrm{H}_{2} \mathrm{O}: \mathrm{H}_{2}$ 3,5pydc stoichiometric ratios and solvent ratios investigated during the high-throughput optimization study for the synthesis of 1-AP. All products indicated as crystalline showed Bragg reflections at the same $2 \theta$ angles. The most crystalline sample of 1-AP (cyan colored, down-pointing triangle) exhibited peaks with the narrowest FWHM, indicating a higher degree of crystalline order. This was obtained with an $\mathrm{Al}\left(\mathrm{NO}_{3}\right)_{3}$. $9 \mathrm{H}_{2} \mathrm{O}: \mathrm{H}_{2}$ 3,5pydc ratio of $1.5: 1$ and a DMF: $\mathrm{H}_{2} \mathrm{O}$ ratio of $9: 1$.

(Figure 2), the synthesis of which was successfully scaled up (see Experimental Section: Optimized scale-up synthesis of 2). With $\mathrm{H}_{2} \mathbf{2}, 4$ pydc only poorly crystalline products were obtained and further synthetic optimization was therefore not pursued.

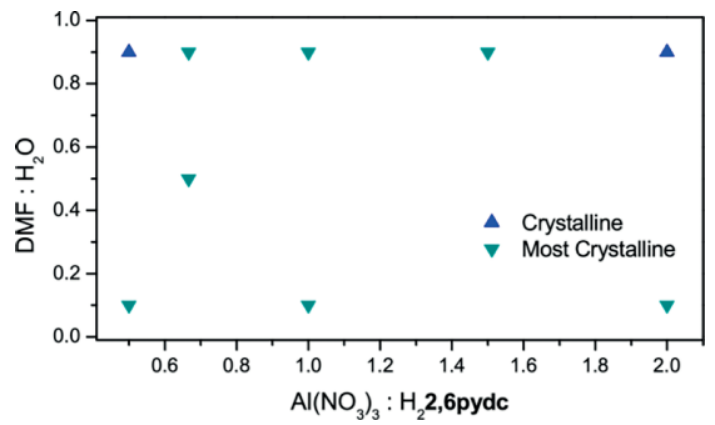

Figure 2. Plot showing the conditions investigated during the highthroughput optimization study of $\mathbf{2}$. All reaction products were crystalline, demonstrating Bragg diffraction peaks, and most demonstrated extremely narrow, single crystal-like Bragg diffraction peaks (indicated as cyan colored, down-pointing triangles) indicating a high degree of crystallographic order. Since highly crystalline $\mathbf{2}$ could be obtained across a wide range of conditions, a reaction with $\mathrm{Al}\left(\mathrm{NO}_{3}\right)_{3}$. $9 \mathrm{H}_{2} \mathrm{O}: \mathrm{H}_{2}$ 2,6pydc $1: 1$ and DMF: $\mathrm{H}_{2} \mathrm{O}$ 1:9 was selected for scaling-up.

\section{Structural Analysis}

Two crystalline compounds were obtained from the synthetic study (see Section Synthesis); both were characterized by powder X-ray diffraction and for compound 2 a singlecrystal X-ray diffraction study could also be performed. The first, CAU-10-pydc, could only be obtained as a microcrystalline powder and for the as-prepared form (1-AP) it was not possible to reliably determine the nature and composition of 
Table 1. Crystallographic parameters from the final Rietveld refinements. See Supporting Information for complete list of refinement parameters.

\begin{tabular}{|c|c|c|c|}
\hline & 1 & $1-\mathrm{H}_{2} \mathrm{O}$ & 2 \\
\hline Conditions & $423 \mathrm{~K} /$ vacuum & ambient & ambient \\
\hline$a / \AA$ & $21.5100(3)$ & $21.4002(3)$ & $7.19193(4)$ \\
\hline$b / \AA$ & & & $10.71549(6)$ \\
\hline$c / \AA$ & $10.51505(17)$ & $10.67754(17)$ & $10.87754(6)$ \\
\hline$\beta /^{\circ}$ & & & $97.5836(4)$ \\
\hline$V / \AA^{3}$ & $4865.11(16)$ & 4889.98(14) & $830.946(8)$ \\
\hline Space Group & $I 4_{1} /$ amd & $I 4_{1} m d$ & $I 2 / m$ \\
\hline $\mathrm{R}_{\mathrm{wp}} / \%$ & 2.99 & 2.44 & 9.62 \\
\hline $\mathrm{R}_{\text {Bragg }} / \%$ & 0.91 & 1.80 & 4.37 \\
\hline$\chi^{2}$ & $22.735^{\text {a) }}$ & 14.948 & 9.672 \\
\hline$\lambda / \AA$ & 0.826952 & 0.826952 & 0.8260285 \\
\hline Detector & PSD & PSD & MAC \\
\hline
\end{tabular}

a) Higher $\chi^{2}$ for $\mathbf{1}$ is due to textural effects in certain reflections, which could not be fitted with strain broadening models. The origin of this is under investigation.

the guest species in the pores. Thus, the structures of the activated compound, under vacuum at $150{ }^{\circ} \mathrm{C}(\mathbf{1})$ and the structure of the hydrated compound (after removal of the guest mol-

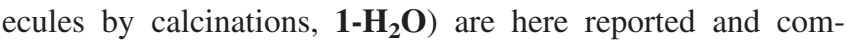
pared. For $\mathbf{2}$ only the crystal structure of the as-prepared compound is reported, since no guest molecules are present and dehydration results in a non-crystalline product.

\section{$[\mathrm{Al}(\mathrm{OH})(3,5 p y d c)](\mathbf{1})$}

The structure of dehydrated (activated) $[\mathrm{Al}(\mathrm{OH})(3,5 p y d c)]$ (1) was obtained by heating a calcined sample of $\mathbf{1}$ to $150{ }^{\circ} \mathrm{C}$ under vacuum for 30 mins, to remove physisorbed water. Synchrotron powder X-ray diffraction (SR-PXRD) data were indexed in the tetragonal space group $14_{1} /$ amd, which is also adopted by other desolvated members of the CAU-10 family of compounds (e.g. CAU-10- $\mathrm{CH}_{3}{ }^{[10]}$ and MIL-160; ${ }^{[13]}$ see Supporting Information for details of systematic absences). An initial model was developed from the desolvated form of CAU-10- $\mathrm{CH}_{3}$ and Rietveld refined against the SR-PXRD data (see Experimental Section for details). Details of the crystallographic parameters of the final refinement are given in Table 1 and a Rietveld plot for the final cycles of refinement is shown in Figure 3a.

Each central $\mathrm{Al}^{3+}$ ion is octahedrally coordinated by six oxygen atoms, two of which - $\mathrm{O} 1$ - are shared in a bridging fashion with neighboring $\mathrm{Al}^{3+}$ sites along the $c$-direction. The shared $\mathrm{O} 1$ and the $\mathrm{Al}$ site are slightly displaced in the $a b$ plane with respect to the $4_{1}$ screw axis, thus helical chains are developed parallel to the $c$-direction (Figure 4a); it should also be noted that the helices of neighboring chains turn in opposite senses. Chains are linked together through two symmetry independent 3,5pydc ${ }^{2-}$ ligands to form a pore network of corrugated unidirectional channels parallel to the $c$-direction, with the N-heteroatom of the ligand ring pointed into the cavity (cf. MIL-160; Figure 4b). The channels consist of larger cavities ( 5.79 $\AA$ free diameter) linked by narrower windows $(3.76 \AA$ free diameter; pore size distribution plot and details of PoreBlazer $^{[21]}$ calculation given in the Supporting Information). For charge balance, the $\mathrm{O} 1$ sites must be protonated; evidence for this can be seen in the IR spectra (see Infrared Spectroscopic Studies).
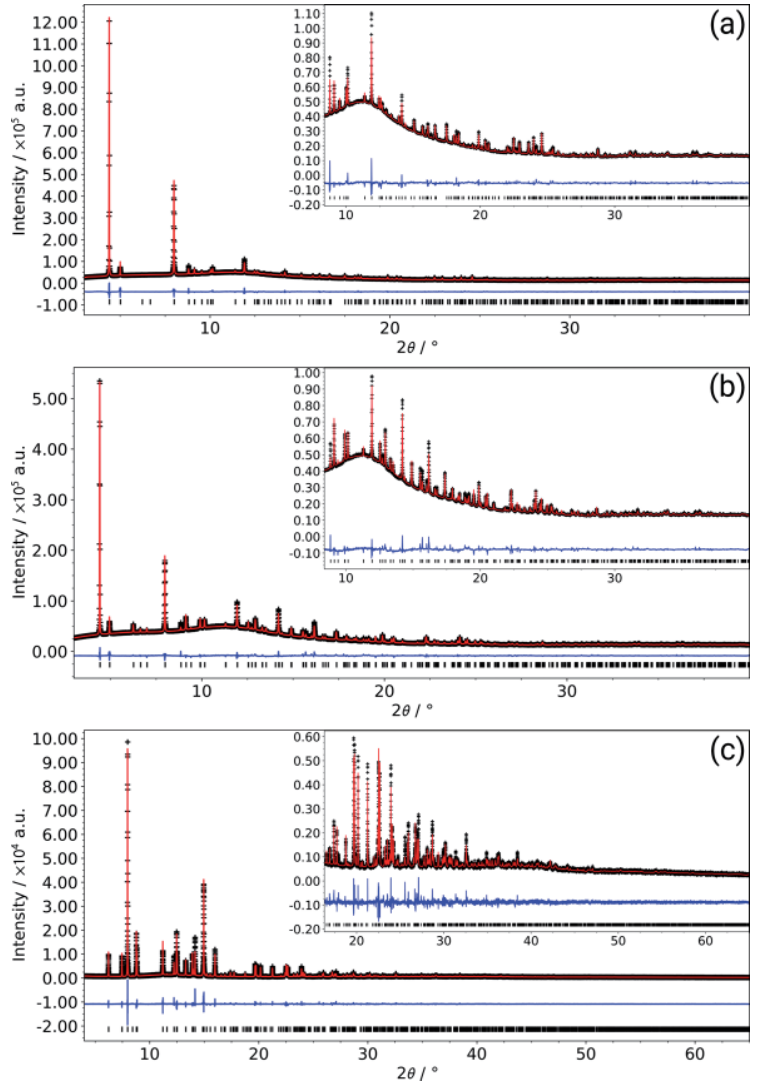

Figure 3. Rietveld plots for the final refinements of $\mathbf{1}$ (a), $\mathbf{1}-\mathbf{H}_{\mathbf{2}} \mathbf{O}$ (b), and 2 (c); insets show enlarged views of the higher $2 \theta$ regions. The black crosses show the measured data; red curve shows the calculated diffraction data; blue curve is the difference curve; and the black vertical lines indicate the expected positions of reflections.

\section{$[\mathrm{Al}(\mathrm{OH})(3,5 p y d c)] \cdot 3.7 \mathrm{H}_{2} \mathrm{O}\left(1-\mathrm{H}_{2} \mathrm{O}\right)$}

The structure of $[\mathrm{Al}(\mathrm{OH})(\mathbf{3 , 5 p y d c})] \cdot 3.7 \mathrm{H}_{2} \mathrm{O}\left(\mathbf{1}-\mathbf{H}_{\mathbf{2}} \mathbf{O}\right)($ Figure 5), was confirmed by Rietveld refinement of SR-PXRD data collected on a sample of CAU-10-pydc, which had been calcined and adsorbed water on cooling $\left(\mathbf{1}-\mathbf{H}_{\mathbf{2}} \mathbf{O}\right)$. Data were collected under ambient conditions and indexed in the noncentrosymmetric space group $I 4_{1} m d$, a sub-group of $I 4_{1} /$ amd adopted by the desolvated compound, which gave the best fit to the observed systematic absences (see Supporting Infor- 
(a)

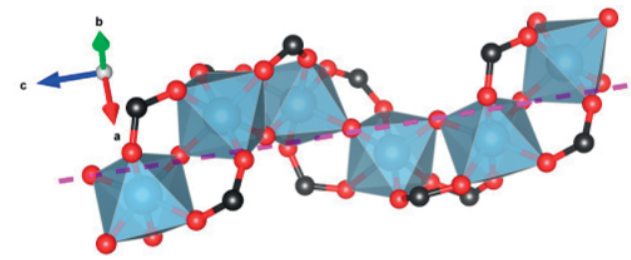

(b)

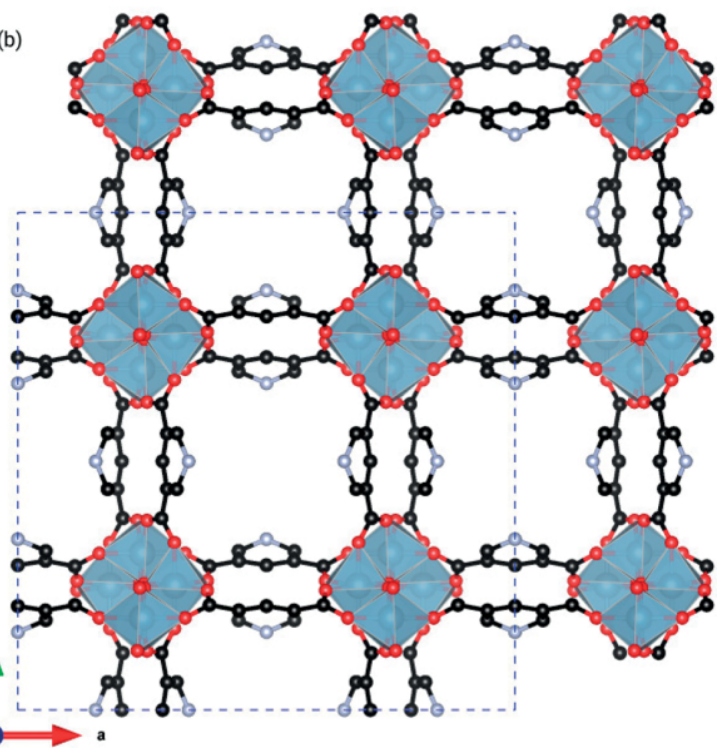

Figure 4. The crystal structure of CAU-10-pydc, 1, showing (a) the structure of the helical chains of corner-sharing $\mathrm{AlO}_{6}$ polyhedra - the pink dashes indicate the $4_{1}$ axis; and (b) a view along the $c$-direction, showing the unidirectional channels. $\mathrm{C}$ atoms in black, $\mathrm{N}$ atoms pale blue, $\mathrm{O}$ atoms red, $\mathrm{Al}$ atoms/polyhedral darker blue. Dashed blue line indicates unit cell edges. Hydrogen atoms are omitted for clarity and as they were not part of the final refinement.

mation for comparison of systematic absences). Although the choice of a non-centrosymmetric space group may seem unusual, it should be noted that a similar transition between centrosymmetric desolvated and non-centrosymmetric hydrated forms is observed for other members of the CAU-10 family, specifically CAU-10- $\mathrm{CH}_{3}{ }^{[10]}$ and MIL-160 ${ }^{[13]}$. In the present case, interactions between adsorbed water molecules and the framework cause a distortion of the framework, which breaks the inversion symmetry. The distortion itself is achieved through the reorientation of the ligands, with ligand $1(\mathrm{C} 1 \mathrm{x}$, $\mathrm{N} 13)$ rotating by ca. $5^{\circ}$ and ligand $2(\mathrm{C} 2 \mathrm{x}, \mathrm{N} 23)$ - which experiences a strong guest-framework interaction - rotating ca. $18^{\circ}$ compared to the higher symmetry $I 4_{1} /$ amd structure (see below). The $I 4_{1} m d \leftrightarrow I 4_{1} /$ amd displacive phase transition is fully reversible.

For the Rietveld refinement, the structure of desolvated $\mathbf{1}$ was used as the starting model. The $\mathrm{O}$ atoms, representing $\mathrm{H}_{2} \mathrm{O}$ molecules, were located in the pores by Fourier difference maps see Experimental Section for details). Full details of the final refinement parameters are given in Table 1 and a Rietvled plot for the final cycles of refinement is given in Figure $3 b$.

The framework connectivity is identical to that of the desolvated structure, with undulating unidirectional channels running along the $c$-direction. The structures differ only in the

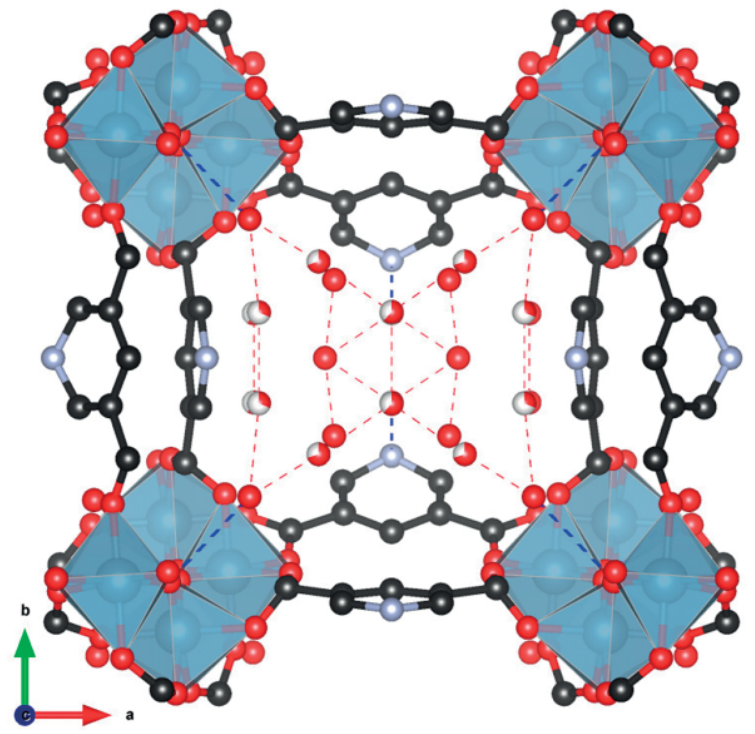

Figure 5. Structure of $\mathbf{1}-\mathbf{H}_{2} \mathbf{O}$, showing the distribution of $\mathrm{H}_{2} \mathrm{O}$ molecules within the channels. Hydrogen-bonding interactions are indicated between guests (red dashes) and guests and framework (blue dashes). Partially filled spheres indicate partially occupied $\mathrm{O}$ atoms $\left(\mathrm{H}_{2} \mathrm{O}\right.$ molecules). Hydrogen atoms are omitted for clarity and as they were not part of the final refinement.

orientation of the ligands (see above). Due to the rotation of one of the ligands into the channel region, the windows are slightly reduced in diameter, whereas the cavities are slightly expanded (cavity diameter: $6.64 \AA$; window diameter: $3.21 \AA$ ). This suggests diffusion in $\mathbf{1}-\mathbf{H}_{\mathbf{2}} \mathbf{O}$ may be more restricted, although a similar pore volume is retained (calculated crystallo-

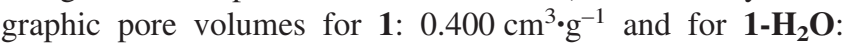
$0.404 \mathrm{~cm}^{3} \cdot \mathrm{g}^{-1}$ ). Water molecules occupying the pore channels are distributed over eight symmetry independent sites, some partially occupied, with a total of $73.9 \mathrm{O}$ atoms per unit cell, equivalent to 59.1 water molecules per unit cell (each site represents 10 electrons of $\mathrm{H}_{2} \mathrm{O}$ not just 8 from an $\mathrm{O}$ atom, thus the overall number of molecules is $20 \%$ lower); this is equivalent to $3.7 \mathrm{H}_{2} \mathrm{O}$ molecules per $\mathrm{Al}^{3+}$ cation in good agreement with TGA and elemental analysis results (see later). Water molecules form a hydrogen bonding network with $\mathrm{O} \cdots \mathrm{O}$ contacts in the range $2.3 \AA$ to $2.9 \AA$, with some similarity to the structure of water ice (Figure 5). Significantly, two of the water molecules make contacts with parts of the framework: N23 $\cdots 0108$ (partially occupied: $41 \%$ ) has a very short contact

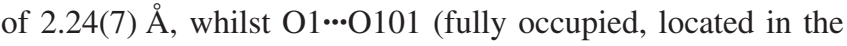
corrugated pocket of the chain) has a longer contact at 2.90(3) A. These interactions, especially the strong interaction with the linker $\mathrm{N}$ atom, are thought to be the driving force for the distortion of the structure which causes the $I 4_{1} /$ amd $\leftrightarrow$ $I 4_{1} m d$ phase transition.

\section{$\left[\mathrm{Al}(\mu-\mathrm{OH})\left(\mathrm{H}_{2} \mathrm{O}\right)(2,6 p y d c)\right]_{2}(2)$}

The structure of $\left[\mathrm{Al}(\mu-\mathrm{OH})\left(\mathrm{H}_{2} \mathrm{O}\right)(\mathbf{2 , 6 p y d c})\right]_{2}(\mathbf{2})$ was solved from a combined approach of synchrotron single crystal and synchrotron powder X-ray diffraction studies (see Experimen- 
tal Section). The structure was initially solved from low temperature single crystal diffraction data, however the refinement proved unstable (see Experimental Section for details). The final room temperature structure was refined from data collected under ambient conditions on an as-prepared sample of the compound. The data were indexed in the monoclinic space group $I 2 / \mathrm{m}$ and subsequently Rietveld refined. Full details of the final refinement parameters are given in Table 1 and a Rietveld plot of the final cycle of refinement is given in Figure 3c.

The structure consists of dimeric, edge-sharing $\left[\mathrm{Al}(\mu-\mathrm{OH})\left(\mathrm{H}_{2} \mathrm{O}\right)(\mathbf{2 , 6 p y d c})\right]_{2}$ units, which link together through a hydrogen-bonding network (Figure 6). The structural motif is reminiscent of two structures formed by $\mathrm{Al}^{3+}$ cations with the linker pyridine-2,4,6-tricarboxylic acid $\left(\mathrm{H}_{3}\right.$ PTC): a closely related molecular dimeric structure $\left[\mathrm{Al}(\mu-\mathrm{OH})\left(\mathrm{H}_{2} \mathrm{O}\right)(\mathrm{HPTC})\right]_{2}$ and the extended three-dimensional framework CAU-16 $\left(\left[\mathrm{Al}(\mu-\mathrm{OH})\left\{\mathrm{Al}(\mu-\mathrm{OH})\left(\mathrm{H}_{2} \mathrm{O}\right)(\mathbf{P T C})\right\}_{2}\right]\right) .{ }^{[19]}$ Indeed, the linkers 2,6pydc ${ }^{2-}$ and PTC $^{3-}$ differ only in that the former lacks a carboxylic acid group at the 4-position. Furthermore, this structural motif has also been reported with $\mathrm{Cr}^{3+}$ and $\mathrm{Mn}^{3+}$ cations, although in those cases the structure was reported in the space group $C 2 / m$. $^{[22,23]}$

(a)

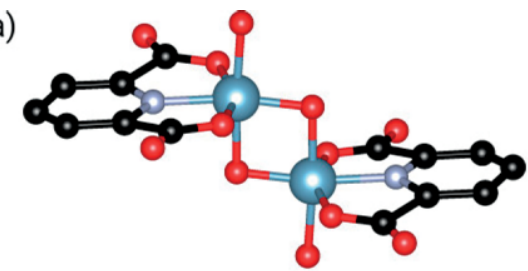

(b)

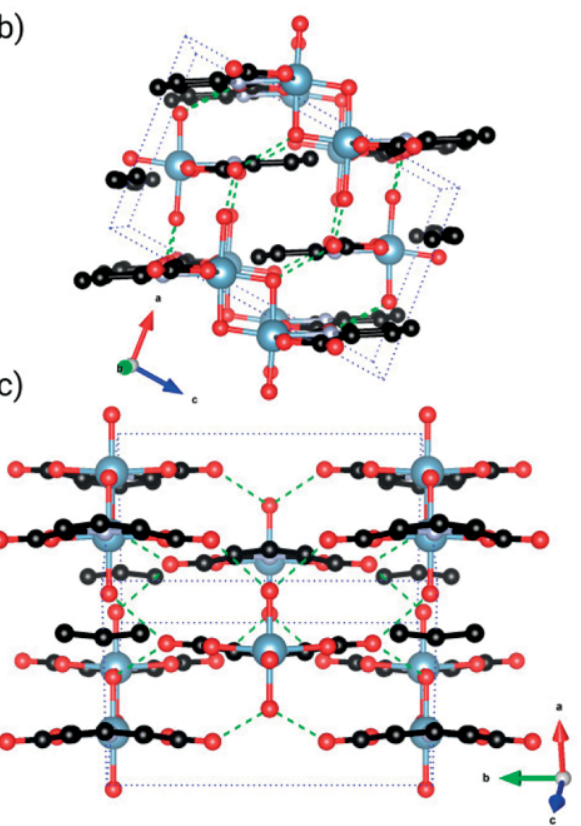

Figure 6. The crystal structure of the dimeric compound $\left[\mathrm{Al}(\mathbf{2}, \mathbf{6 p y d c})(\mu-\mathrm{OH})\left(\mathrm{H}_{2} \mathrm{O}\right)\right]_{2}$ (2) showing (a) the dimeric units and the packing within the unit cell viewed (in perspective) along the 010 (b) and 101 (c) directions. Green dashed bonds indicated hydrogen bonds. Blue dotted lines indicate the unit cell edges. Hydrogen atoms are omitted for clarity and as they were not part of the final refinement.
In the present compound $\mathbf{2}$, the asymmetric unit consists of one Al site, half a 2,6pydc ${ }^{2-}$ unit, one $\mu-\mathrm{OH}$, and one $\mathrm{H}_{2} \mathrm{O}$ molecule. The center of mass of all four of these components is located on the mirror plane. Thus, each Al site is octahedrally coordinated by five $\mathrm{O}$ atoms - two from monodentate carboxylic acid groups, two from $\mu-\mathrm{OH}$ groups and one from a terminal $\mathrm{H}_{2} \mathrm{O}$ molecule - and one $\mathrm{N}$ atom from the pyridinyl ring. Typically the coordination chemistry of $\mathrm{Al}^{3+}$ is dominated by oxophillic interactions. ${ }^{[24,25]}$ In the structure of $\mathbf{2}$, coordination by the pyridinyl $\mathrm{N}$ atom occurs due to the chelating nature of the $\mathrm{O} / \mathrm{N} / \mathrm{O}$ pocket. Two of these monomeric $\left[\mathrm{Al}(\mu-\mathrm{OH})\left(\mathrm{H}_{2} \mathrm{O}\right)(\mathbf{2}, \mathbf{6 p y d c})\right]$ units link in an edge-sharing fashion through the two $\mu-\mathrm{OH}$ groups to form dimers. Dimers interact through weaker and stronger hydrogen-bonding interactions between the carboxylate $\mathrm{O} 2$ and terminal water $\mathrm{O} 3$ sites above and below the plane of the 2,6pydc linkers [2.554(4) $\AA$ and 3.112(4) $\AA$, respectively]. Dimers are densely packed within the cell and no porosity is developed.

\section{Thermoanalytical Studies}

Both compounds $\mathbf{1}$ and $\mathbf{2}$ were analyzed by thermogravimetric analysis (TGA) and elemental analysis to understand the composition and importantly the solvent molecules occluded in their pore space.

\section{$[\mathrm{Al}(\mathrm{OH})(3,5 p y d c)] \cdot X(1-\mathrm{AP})$}

The TGA trace for 1-AP shows two principal weight losses, the first, beginning at $25^{\circ} \mathrm{C}$ and complete by $270{ }^{\circ} \mathrm{C}$, is associated with the loss of guests from the pore space, and the second, starting at $415^{\circ} \mathrm{C}$ and finished by $550{ }^{\circ} \mathrm{C}$, is related to destruction of the framework (Figure 7, top). The trace of $\mathbf{1 - H _ { 2 }} \mathrm{O}$ shows a similar pattern of weight loses, except that the first step, the desolvation process, is complete by $80^{\circ} \mathrm{C}$ (see below).

In 1-AP, the desolvation process occurs in two step: $25^{\circ} \mathrm{C}$ to $110{ }^{\circ} \mathrm{C}$ is attributed to the loss of 3.4 molecules of water from the pores $(20.2 \mathrm{wt} \%$; water content calculated assuming a final product of $\mathrm{Al}_{2} \mathrm{O}_{3}$ ); and $140{ }^{\circ} \mathrm{C}$ to $270{ }^{\circ} \mathrm{C}$, assigned to the loss of DMF or breakdown products thereof $(8.0 \mathrm{wt} \%$, equating to 0.3 molecules of DMF per $\mathrm{Al}$ ). As ethanol is also used in the washing of the product, it is likely that some is present as guest molecules. Due to the additional complexity of modeling this however, it has not been considered in the analysis of the TGA data. No further weight losses are observed up to $415^{\circ} \mathrm{C}$, showing the high stability of the framework. Above $415^{\circ} \mathrm{C}$, collapse of the framework occurs, also in a two-step process: between $415^{\circ} \mathrm{C}$ and $440{ }^{\circ} \mathrm{C}$, a weight loss of $8 \mathrm{wt} \%$ occurs, which is assigned to dehydroxylation of the helical chains (cf. for example, MIL-91 ${ }^{[26]}$ ). This is rapidly followed by a second weight loss from $465^{\circ} \mathrm{C}$ to $550{ }^{\circ} \mathrm{C}$ (42.4 wt \%) corresponding to the loss of linker molecules (observed: 0.78 molecules per $\mathrm{Al}$; expected: 1.0; discrepancy due to retention of some $\mathrm{O}$ atoms from linker in final product).

\section{$[\mathrm{Al}(\mathrm{OH})(3,5 p y d c)] \cdot 3.7 \mathrm{H}_{2} \mathrm{O}\left(1-\mathrm{H}_{2} \mathrm{O}\right)$}

To better understand the thermal behavior of compound $\mathbf{1}$ it was deemed necessary to remove the occluded DMF/break- 

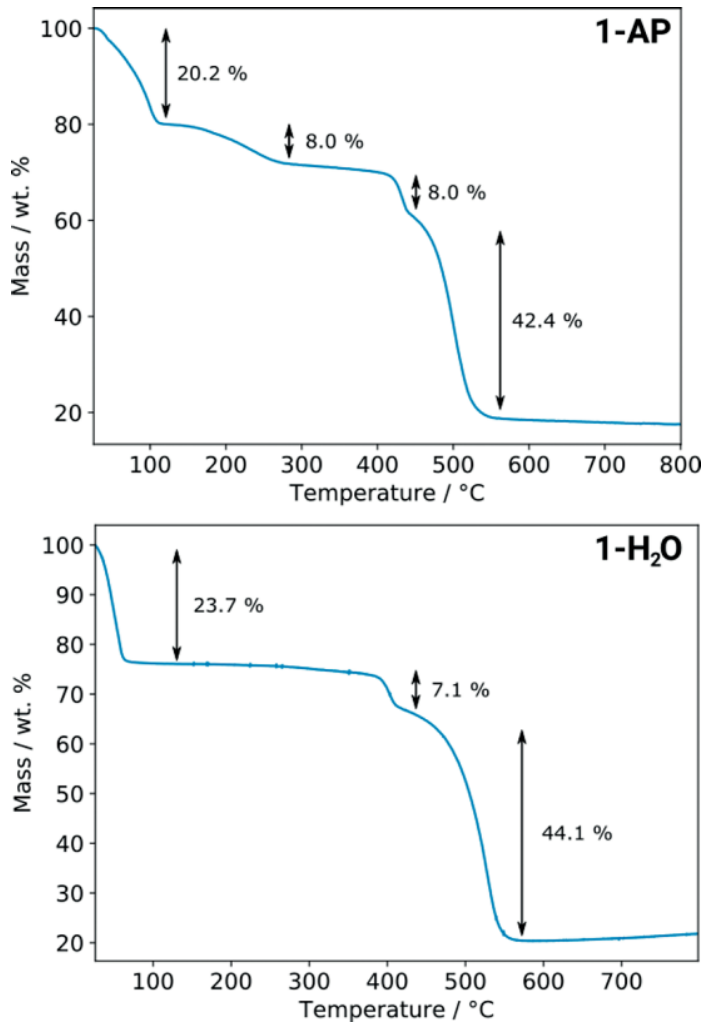

Figure 7. TGA plots for as-prepared $\mathbf{1}$ (1-AP) (top) and $\mathbf{1}$ rehydrated after calcination at $250{ }^{\circ} \mathrm{C}\left(\mathbf{1}-\mathbf{H}_{2} \mathbf{O}\right)$ (bottom) under flowing air from room temperature to $800{ }^{\circ} \mathrm{C}$. Principal mass losses are indicated.

down products. To that end a sample of 1-AP was heated to $250{ }^{\circ} \mathrm{C}$ in a tube furnace in a flow of nitrogen gas for $3 \mathrm{~h}$. The final product was found to have a pale cream color and a PXRD pattern showed no significant changes (see Structural Analysis), confirming the thermal stability of the framework.

$\mathbf{1 - H _ { 2 }} \mathbf{O}$ shows a similar pattern of weight losses during TGA measurements as 1-AP (Figure 7, bottom): an initial weight loss attributed to desolvation begins at $25^{\circ} \mathrm{C}$ and is complete by $80^{\circ} \mathrm{C}$; whilst a second group of weight losses occur from $380{ }^{\circ} \mathrm{C}$ to $570{ }^{\circ} \mathrm{C}$. In $\mathbf{1}-\mathbf{H}_{\mathbf{2}} \mathbf{O}$, desolvation proceeds through a single step process, attributed to the loss of 3.7 molecules of water per $\mathrm{Al}$ atom (observed: $23.7 \mathrm{wt} \%$; expected: $24.8 \mathrm{wt} \%-$ calculated for $\left.\left[\mathrm{Al}(\mathrm{OH})\left(\mathrm{C}_{7} \mathrm{H}_{3} \mathrm{NO}_{4}\right)\right] \cdot 3.7 \mathrm{H}_{2} \mathrm{O}\right)$. This is in excellent agreement with the crystallographically determined number of water molecules. No weight losses are observed between 80 and $380{ }^{\circ} \mathrm{C}$, further emphasizing the thermal stability of the framework. However the onset of framework decomposition is approximately $35{ }^{\circ} \mathrm{C}$ degrees lower than for 1AP. This difference is thought to be due to the introduction of defects in the framework during the activation procedure: that is the thermal cleavage of some framework bonds, but without the liberation of framework components. $\mathbf{1}-\mathbf{H}_{\mathbf{2}} \mathbf{O}$ shows a similar two-step decomposition process to 1-AP, with the first step ( 380 to $425{ }^{\circ} \mathrm{C} ; 7.1 \mathrm{wt} \%$, expected: $6.7 \mathrm{wt} \%$ ) again attributed to the dehydroxylation of the framework and the second step ( 450 to $570{ }^{\circ} \mathrm{C} ; 44.1 \mathrm{wt} \%$, expected $43.6 \mathrm{wt} \%$ - assuming one $\mathrm{O}$ atom retained in oxide product).
Elemental analysis data are in good agreement with TGA and gave $\mathrm{C} 29.60, \mathrm{H} 4.49$, N $5.04 \%$ (calculated, assuming composition $\mathrm{Al}(\mathrm{OH})\left(\mathrm{C}_{7} \mathrm{H}_{3} \mathrm{NO}_{4}\right) \cdot 3.7 \mathrm{H}_{2} \mathrm{O}: \mathrm{C} 30.49, \mathrm{H} 4.17, \mathrm{~N}$ $5.07 \%)$.

$\left[\mathrm{Al}(\mu-\mathrm{OH})\left(\mathrm{H}_{2} \mathrm{O}\right)(2,6 \mathrm{pydc})\right]_{2}(2)$

The TGA trace of $\mathbf{2}$ shows negligible weight loss up $250^{\circ} \mathrm{C}$ : this reflects the non-porous, molecular nature of the compound (Figure 8). Between 250 and $300{ }^{\circ} \mathrm{C}$, the compound loses $2.5 \mathrm{wt} \%$, which is attributed to a partial dehydroxylation of the dimeric complex [7 wt \% calculated for full dehydroxylation, based on composition $\left.\left[\mathrm{Al}\left(\mathrm{C}_{7} \mathrm{H}_{3} \mathrm{NO}_{4}\right)(\mu-\mathrm{OH})\left(\mathrm{H}_{2} \mathrm{O}\right)\right]_{2}\right]$. Above $325^{\circ} \mathrm{C}$, the compound undergoes a significant weight loss $(75.1 \mathrm{wt} \%)$, indicated in the TGA trace as a step with varying gradient which is complete by $550{ }^{\circ} \mathrm{C}$. This step is assigned to the loss of linker molecules and remaining hydroxide groups/water molecules (72.7 wt \% expected for decomposition of linker alone). The complex nature of the step reflects the multiple processes - linker loss, $\mathrm{H}_{2} \mathrm{O} / \mathrm{OH}$ group elimination - which are occurring.

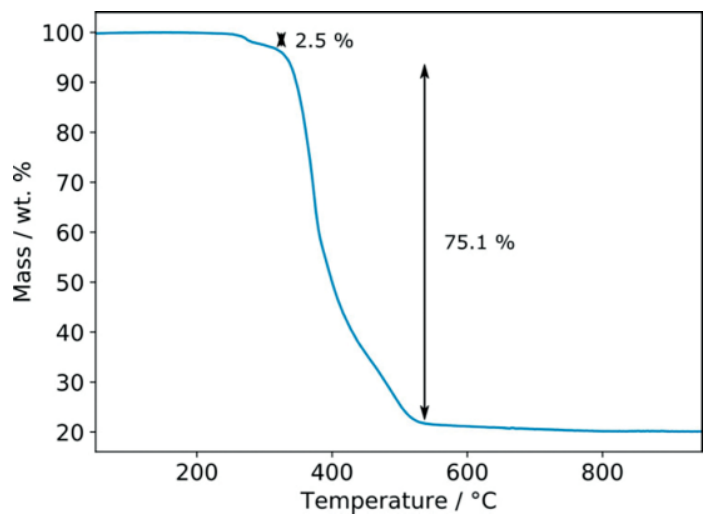

Figure 8. TGA plot for $\left[\mathrm{Al}(\mathbf{2 , 6 p y d c})(\mu-\mathrm{OH})\left(\mathrm{H}_{2} \mathrm{O}\right)\right]_{2}$ (2) under flowing air from room temperature to $800^{\circ} \mathrm{C}$. Principal mass losses are indicated.

Elemental analysis results are in good agreement with the proposed composition of $\mathbf{2}$ and gave $\mathrm{C} 36.50, \mathrm{H} 2.82, \mathrm{~N} 6.61 \%$ (calculated for a composition of $\mathrm{Al}(\mathrm{OH})\left(\mathrm{H}_{2} \mathrm{O}\right)\left(\mathrm{C}_{7} \mathrm{H}_{3} \mathrm{NO}_{4}\right)$ : C 37.02, H 2.66 , N $6.18 \%$ ).

\section{Infrared Spectroscopic Studies}

$[\mathrm{Al}(\mathrm{OH})(3,5 p y d c)] \cdot \mathrm{X}(1-\mathrm{AP})$ and $[\mathrm{Al}(\mathrm{OH})(3,5 p y d c)] \cdot 3.7 \mathrm{H}_{2} \mathrm{O}$ $\left(1-\mathrm{H}_{2} \mathrm{O}\right)$

Infrared spectra were measured for both the as-prepared compound $\mathbf{1}$ and for the compound after calcination at $300{ }^{\circ} \mathrm{C}$ (when it contains only $\mathrm{H}_{2} \mathrm{O}$ guests). Both spectra show the same principle absorption bands (Figure 9; see Supporting Information for complete assignment). Differences between the two spectra are due to the different guest species present: in 1-AP guests are unknown breakdown products from DMF, water and possibly ethanol (the latter two from washing of the product after synthesis); in $\mathbf{1}-\mathbf{H}_{\mathbf{2}} \mathbf{O}, \mathrm{H}_{2} \mathrm{O}$ molecules are the only guest species. In 1-AP, there are two distinct peaks at 3625 
and $3591 \mathrm{~cm}^{-1}$ which are attributed to an $\mathrm{N}-\mathrm{H}$ stretch and the chain $\mathrm{OH}$ group respectively. In the same region in $\mathbf{1}-\mathbf{H}_{\mathbf{2}} \mathbf{O}$, the peak at $3603 \mathrm{~cm}^{-1}$ is attributed to the chain $\mathrm{OH}$ group, the slight shift being due to changes in the interactions of this group with other guest species. The observation of an $\mathrm{OH}$ stretch for the framework of $\mathbf{1}-\mathbf{H}_{\mathbf{2}} \mathbf{O}$ confirms that cornershared $\mathrm{O}$ atoms of the chains must be protonated. The broad adsorption in both spectra, centered around $3350 \mathrm{~cm}^{-1}$, is narrower and reduced in intensity in $\mathbf{1}-\mathbf{H}_{\mathbf{2}} \mathbf{O}$, reflecting the reduced diversity of hydrogen-bonding interactions when only $\mathrm{H}_{2} \mathrm{O}$ is present compared to the mixture of $\mathrm{H}_{2} \mathrm{O}$ and unknown guests in 1-AP. In the lower wavenumber region of the spectra, further differences are observed with peaks at 1663 and $1101 \mathrm{~cm}^{-1}$ absent from the spectrum of $\mathbf{1}-\mathbf{H}_{\mathbf{2}} \mathbf{O}$. These peaks can be assigned to stretching vibrations expected for amides (e.g. $\mathrm{C}=\mathrm{O}$ or $\mathrm{C}-\mathrm{N}$ ). Given the observed differences in the spectra and the reaction conditions, it is hypothesized that the unknown guest species are likely either DMF, dimethylamine, formic acid, or other related DMF breakdown products.

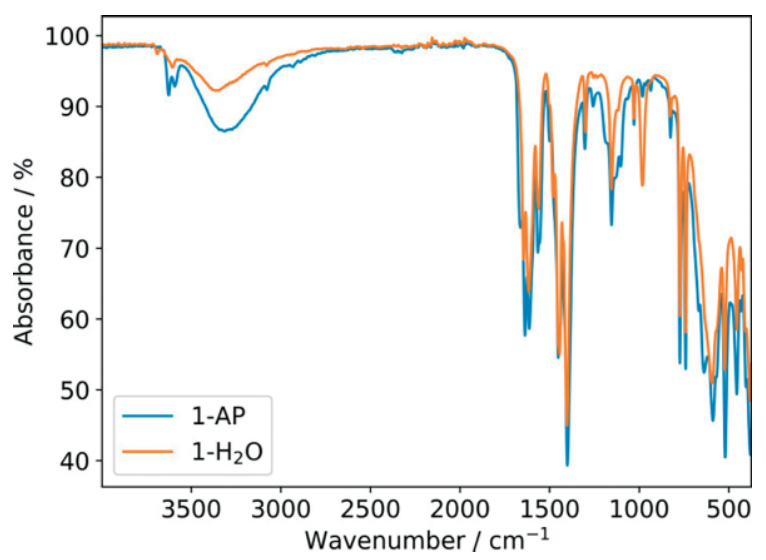

Figure 9. FT-IR spectra for as-prepared $\mathbf{1}$ (1-AP) (blue curve) and $\mathbf{1}$ after calcination at $300{ }^{\circ} \mathrm{C}$ with $\mathrm{H}_{2} \mathrm{O}$ guests $\left(\mathbf{1}-\mathbf{H}_{\mathbf{2}} \mathbf{O}\right)$ (orange curve). Differences between the plots are attributed to the unidentified guest species thought to be occupying the pores of the as-prepared materials and responsible for the yellow color.

\section{$\left[\mathrm{Al}(\mu-\mathrm{OH})\left(\mathrm{H}_{2} \mathrm{O}\right)(2,6 \mathrm{pydc})\right]_{2}(2)$}

The infrared spectrum of $\mathbf{2}$ is similar to the reported compound $\left[\mathrm{Al}(\mu-\mathrm{OH})\left(\mathrm{H}_{2} \mathrm{O}\right)(\mathrm{HPTC})\right]_{2} \cdot{ }^{[19]} \mathrm{A}$ broad absorption band centered around $3540 \mathrm{~cm}^{-1}$ is assigned to an hydrogen bonding $\mathrm{OH}$ group, as anticipated from the crystal structure (Figure 10). This compares to $3432 \mathrm{~cm}^{-1}$ in the reported compound, indicating the stronger nature of the bond in the present compound. Absorption bands for the ligand are also similar to those of $\left[\mathrm{Al}(\mu-\mathrm{OH})\left(\mathrm{H}_{2} \mathrm{O}\right)(\mathrm{HPTC})\right]_{2}$, e.g. $1651 \mathrm{~cm}^{-1}-$ the coordinated $\mathrm{C}=\mathrm{O}$ stretch; and $1585 \mathrm{~cm}^{-1}$, the $\mathrm{O}-\mathrm{C}-\mathrm{O}$ anti-symmetric stretch (see Supporting Information for complete assignment).

\section{$\mathrm{N}_{2}$ Sorption Studies}

CAU-10-pydc, compound 1, has a unidirectional channel structure, similar to that of other members of the CAU-10 family of compounds. To assess the porosity of this compound,

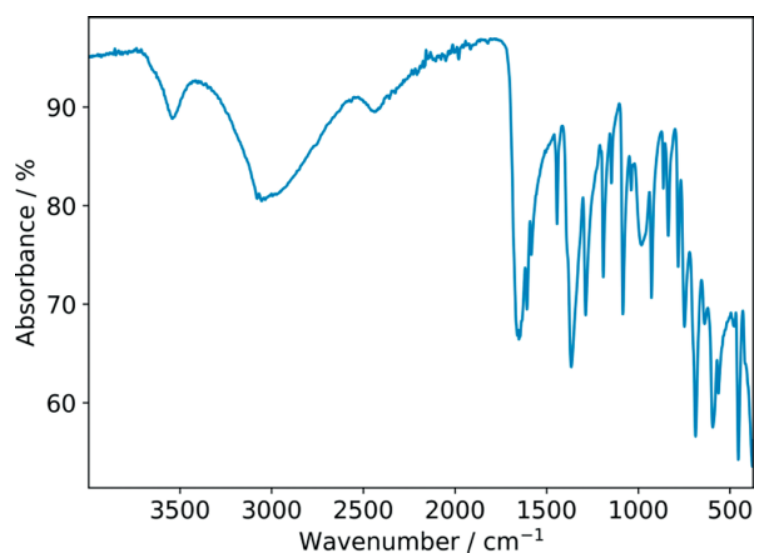

Figure 10. FT-IR spectrum of $\left[\mathrm{Al}(\mu-\mathrm{OH})\left(\mathrm{H}_{2} \mathrm{O}\right)(\mathbf{2}, \mathbf{6 p y d c})\right]_{2}$ (2). The positions of the $\mathrm{O}-\mathrm{H}$ and ligand stretching modes are consistent with those reported for the related dimeric $\mathrm{Al}^{3+}$ compound $\left[\mathrm{Al}(\mu-\mathrm{OH})\left(\mathrm{H}_{2} \mathrm{O}\right)(\mathrm{HPTC})\right]_{2}{ }^{[19]}$

a $\mathrm{N}_{2}$ sorption isotherm at $77 \mathrm{~K}$ was measured on a sample of 1-H2O. The sample was activated by heating to $150{ }^{\circ} \mathrm{C}$ for $3 \mathrm{~h}$ under vacuum of $1 \times 10^{-4}$ mbar to ensure all guests were removed. The adsorption isotherm shows a Type I shape up to $p / p_{0} \approx 0.06$. Above this point, a second adsorption step occurs, the origin of which is under investigation (Figure 11). No hysteresis is observed during desorption, including over the step region.

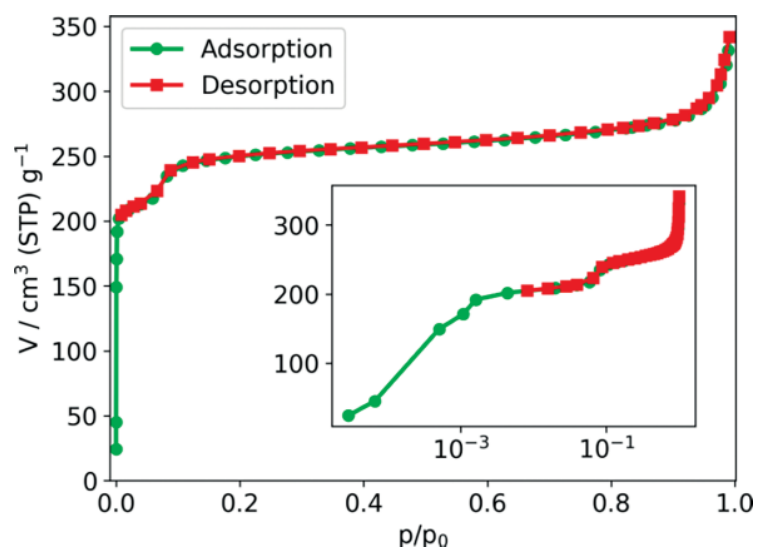

Figure 11. $\mathrm{N}_{2}$ sorption isotherm for CAU-10-pydc, 1, at $77 \mathrm{~K}$, showing the adsorption curve (green with circle marker) and the desorption curve (red with square markers). Inset shows a semilog plot of the sorption data, showing details of the initial adsorption step.

Using the first adsorption step, a BET surface area of $884 \mathrm{~m}^{2} \cdot \mathrm{g}^{-1}$ was determined, which is in good agreement with other members of the CAU-10 family of compounds. ${ }^{[10]}$ Dubinin-Radushkevitch analysis for $\mathrm{N}_{2}$ at $77 \mathrm{~K}$ gives a micropore volume of $0.34 \mathrm{~cm}^{3} \cdot \mathrm{g}^{-1}\left(N_{0}=9.69 \mathrm{mmol} \cdot \mathrm{g}^{-1}\right){ }^{[27]}$ This compares to a theoretical micropore volume, calculated using PoreBlazer, ${ }^{[21]}$ of $0.40 \mathrm{~cm}^{3} \cdot \mathrm{g}^{-1}$. Differences between the calculated and observed micropore volume are attributed to pore blocking within the real framework and that the simulation uses the Universal Force Field ${ }^{[28]}$ as a model for interactions, which may not be applicable in all cases. 


\section{Conclusions}

From three isomeric pyridinedicarboxylic acid linkers, in which the carboxylic acid groups are meta-substituted relative to one another, two new aluminum carboxylate coordination compounds were prepared. The substitution position of the pyridinyl $\mathrm{N}$ atom relative to the carboxylate groups strongly influences the composition and structures formed. In the lowest symmetry case of 2,4-pyridinedicarboxylic acid, only poorly crystalline products could be obtained. For the high-symmetry, 3,5-pyridinedicarboxylic acid, an extended coordination polymer, 1, isostructural to CAU-10 is obtained. For the equally high symmetry 2,6-pyridinedicarboxylic acid, the $\mathrm{O} /$ $\mathrm{N} / \mathrm{O}$ chelating pocket forces $\mathrm{N}$ to engage in $\mathrm{Al}-\mathrm{N}$ bonding and leads to the formation of a non-porous, molecular compound, 2 , consisting of dimeric Al-O units. The structure is similar to the dimeric linkers observed in CAU-16 and the structure of $\left[\mathrm{Al}(\mu-\mathrm{OH})\left(\mathrm{H}_{2} \mathrm{O}\right)(\mathrm{HPTC})\right]_{2}$, and is also a structural analogue of two transition metal complexes, formed with $\mathrm{Cr}^{3+}$ and $\mathrm{Mn}^{3+}$ ions and 2,6-pyridinedicarboxylic acid. ${ }^{[19,22,23]}$

The CAU-10 analogue, CAU-10-pydc, crystallizes as a bright yellow compound (1-AP), which is thermally stable to the removal, at high temperature, of unknown guest molecules (derived from the synthetic procedure). On cooling the compound adsorbs aerial water to yield $\mathbf{1}-\mathbf{H}_{\mathbf{2}} \mathbf{O}$. Hydrated CAU10-pydc $\left(\mathbf{1}-\mathbf{H}_{\mathbf{2}} \mathbf{O}\right)$ exhibits symmetry consistent with the noncentrosymmetric space group $\mathrm{I}_{1} \mathrm{md}$. Elemental analysis and TGA indicated that there are 3.7 water molecules per $\mathrm{Al}^{3+}$ cation, which is in excellent agreement with the number of water molecules identified in the Rietveld refinement. Removal of the guest water molecules causes a displacive phase transition with consequent change of symmetry to the centrosymmetric space group $I 4_{1} / a m d$. Such behavior is known for other members of the CAU-10 family of compounds. The driving force for the phase transition in CAU-10-pydc is the interaction of guest water molecules with the framework pyridinyl $\mathrm{N}$ atoms, which cause a distortion of the framework. The desolvated form of $\mathbf{1}$ is porous to $\mathrm{N}_{2}$ with a BET surface area of $884 \mathrm{~m}^{2} \cdot \mathrm{g}^{-1}$ and a pore-volume of $0.34 \mathrm{~cm}^{3} \cdot \mathrm{g}^{-1}$, in good agreement with simulation.

\section{Experimental Section}

High Throughput Discovery Synthesis: For the discovery array with $\mathrm{H}_{2}$ 3,5pydc, the linker and six aluminum salts $\left[\mathrm{AlCl}_{3} \cdot 6 \mathrm{H}_{2} \mathrm{O}, \mathrm{Al}\left(\mathrm{NO}_{3}\right)_{3}\right.$. $9 \mathrm{H}_{2} \mathrm{O}, \mathrm{Al}(\mathrm{OH})_{3}, \mathrm{Al}(\mathrm{OH})(\mathrm{AcO})_{2}, \mathrm{Al}_{2} \mathrm{O}_{3}$, and $\left.\mathrm{Al}_{2}\left(\mathrm{SO}_{4}\right)_{3} \cdot 18 \mathrm{H}_{2} \mathrm{O}\right]$ were loaded into Teflon ${ }^{\circledR}$ liners of a 24 reactor multiclave in a 1:1 stoichiometry. ${ }^{[20]}$ A solvent mixture of DMF and water (1500 $\mu \mathrm{L}$; ratio: 9:1) was added to half fill the reactors and give a reaction concentration of $0.4 \mathrm{~mol} \cdot \mathrm{dm}^{-3}$. Reactions were heated at a ramp rate of $2.2^{\circ} \mathrm{C} \cdot \mathrm{min}^{-1}$ to $150{ }^{\circ} \mathrm{C}$ and held at this temperature for $12 \mathrm{~h}$ before cooling back to room temperature. A crystalline powder of 1-AP was obtained from $\mathrm{AlCl}_{3}, \mathrm{Al}(\mathrm{NO})_{3}$, and $\mathrm{Al}(\mathrm{OH})(\mathrm{AcO})_{2}$; the highest crystallinity was obtained with $\mathrm{Al}\left(\mathrm{NO}_{3}\right)_{3}$.

\section{Reaction Optimization}

$\mathrm{Al}\left(\mathrm{NO}_{3}\right)_{3}$ with $\mathrm{H}_{2}$ 3,5pydc: $\mathrm{Al}\left(\mathrm{NO}_{3}\right)_{3} \cdot 9 \mathrm{H}_{2} \mathrm{O}$ and $\mathrm{H}_{2}$ 3,5pydc in stoichiometric ratio $1: 1$ were loaded into Teflon ${ }^{\circledR}$ reactors of a 24 reactor multiclave. To this were added DMF and $\mathrm{H}_{2} \mathrm{O}$ solvents in ratios 10:0, 8.33:1.67, 6.67:3.33, 5:5, 3.33:6.67, 1.67:8.33 and $0: 10(1500 \mu \mathrm{L}$ total volume). In addition to these, three reactions with $\mathrm{Al}\left(\mathrm{NO}_{3}\right)_{3} \cdot 9 \mathrm{H}_{2} \mathrm{O}$ and $\mathrm{H}_{2}$ 3,5pydc ratios 1:1.5, 1.5:1, and 2:1 with DMF and $\mathrm{H}_{2} \mathrm{O}$ in a constant ratio of $9: 1(1500 \mu \mathrm{L}$ total volume) were also undertaken, yielding a total of 10 reactions studied in parallel. The reaction concentrations were kept constant $\left(0.4 \mathrm{~mol} \cdot \mathrm{dm}^{-3}\right)$. The reactor was heated to $150{ }^{\circ} \mathrm{C}$ for $12 \mathrm{~h}$ before cooling back to room temperature. The most crystalline product was obtained for the stoichiometric ratio 1:1.5 and solvent ratio 9:1 (Figure 1) Reactions with more DMF than $\mathrm{H}_{2} \mathrm{O}$ gave crystalline 1-AP as the product; reactions with equal amounts of DMF and water or more water gave X-ray amorphous products or recrystallized ligand (Figure 1).

The reaction temperature was optimized by taking the optimized conditions and performing three further identical reactions at 80,120, and $160{ }^{\circ} \mathrm{C}$ in culture tubes. A temperature of $120^{\circ} \mathrm{C}$ was found to produce the most crystalline product.

$\mathrm{Al}\left(\mathrm{NO}_{3}\right)_{3}$ with $\mathrm{H}_{2}$,, 4 pydc or $\mathrm{H}_{2}$ 2,6pydc: Two high-throughput optimization arrays were used to investigate reactions of $\mathrm{Al}\left(\mathrm{NO}_{3}\right)_{3} \cdot 9 \mathrm{H}_{2} \mathrm{O}$ with $\mathrm{H}_{2}$ 2,4pydc and $\mathrm{H}_{2}$ 2,6pydc. $\mathrm{Al}\left(\mathrm{NO}_{3}\right)_{3} \cdot 9 \mathrm{H}_{2} \mathrm{O}$ and the respective ligand were loaded into Teflon ${ }^{\circledR}$ reactors of a 24 reactor multiclave in stoichiometric ratios varying between 2:1 and 1:2. DMF: $\mathrm{H}_{2} \mathrm{O}$ solvent mixtures in ratios of 9:1, 1:1, or 1:9 were added; with $\mathrm{H}_{2} \mathbf{2}$,6pydc pure ethanol and 2-propanol were also investigated as solvents. The reactions had volumes of $1500 \mu \mathrm{L}$ (half-filling the reactors) and concentrations of $0.4 \mathrm{~mol} \cdot \mathrm{dm}^{-3}$, and were heated to $120{ }^{\circ} \mathrm{C}$ for $18 \mathrm{~h}$ before cooling back to room temperature.

With $\mathrm{H}_{2} \mathbf{2}$,6pydc large, white blocky crystals of a phase labeled 2 were obtained from all reactions. The most crystalline products were obtained with an $\mathrm{Al}\left(\mathrm{NO}_{3}\right)_{3}: \mathrm{H}_{2}$ 2,6pydc stoichiometry of $1: 1.5$ and DMF: $\mathrm{H}_{2} \mathrm{O}$ ratio of $1: 9$; therefore these conditions were used for the scale-up synthesis. By contrast, with $\mathrm{H}_{2} \mathbf{2}, \mathbf{4}$ pydc only poorly crystalline products were obtained.

\section{Optimized Scale-Up Syntheses}

Synthesis of 1: A mixture of solid $\mathrm{H}_{2} 3,5$ pydc $(0.80 \mathrm{~g}, 4.80 \mathrm{mmol})$ and $\mathrm{Al}\left(\mathrm{NO}_{3}\right)_{3} \cdot 9 \mathrm{H}_{2} \mathrm{O}(1.20 \mathrm{~g}, 3.20 \mathrm{mmol})$ was loaded into a $100 \mathrm{~mL}$ Duran glass screw-top jar. To this was added DMF $(18 \mathrm{~mL})$ and distilled water $(2 \mathrm{~mL})$ to yield a total reaction volume of $20 \mathrm{~mL}$ (concentration: $0.4 \mathrm{~mol} \cdot \mathrm{dm}^{-3}$ ). The reaction was stirred until clear before being sealed. The reaction was then heated at $120^{\circ} \mathrm{C}$ for $18 \mathrm{~h}$ in a convection oven, after which time a fine, bright yellow precipitate was observed at the bottom of the reactor. The reactions were allowed to cool naturally to room temperature. The solid was separated by centrifugation in the mother liquor (3000 rpm, $30 \mathrm{~min}$ ). The supernatant was carefully decanted off. Afterwards, the solid was washed with ethanol $(20 \mathrm{~mL})$ and centrifuged again (3000 rpm, $10 \mathrm{~min}$ ) to remove remaining DMF. Washing was repeated once more before the solid was dried in vacuo at $100{ }^{\circ} \mathrm{C}$ to remove remaining) ethanol. The dry yellow solid was then transferred to an alumina boat and calcined at $250{ }^{\circ} \mathrm{C}$ in flowing $\mathrm{N}_{2}$ for $3 \mathrm{~h}$. The final cream-colored product was allowed to cool back to room temperature overnight in flowing $\mathrm{N}_{2}$. The final solid had a mass of $0.270 \mathrm{~g}$ ( $0.90 \mathrm{mmol}$ (ex. solvent); yield: $28 \%)$.

Synthesis of 2: A mixture of $\mathrm{Al}\left(\mathrm{NO}_{3}\right) \cdot 9 \mathrm{H}_{2} \mathrm{O}(0.375 \mathrm{~g}, 1.0 \mathrm{mmol})$ and $\mathrm{H}_{2}$ 2,6pydc $(0.167 \mathrm{~g}, 1.0 \mathrm{mmol})$ was loaded into a $20 \mathrm{~mL}$ microwave vial. To this was added DMF $(0.5 \mathrm{~mL})$ and $\mathrm{H}_{2} \mathrm{O}(4.5 \mathrm{~mL})$ to give a final ratio of 1:9 and a final concentration of $0.4 \mathrm{mmol} \cdot \mathrm{dm}^{-3}$. The vial was sealed and heated in a convection oven to $120{ }^{\circ} \mathrm{C}$ for $15 \mathrm{~h}$ before being cooled back to room temperature. The final product of white 
blocky crystals was separated by vacuum filtration and washed with distilled water $(2 \times 10 \mathrm{~mL})$. The final solid had a mass of $0.218 \mathrm{~g}$ (0.48 mmol; yield: $96 \%$, based on $\mathrm{Al}$ ).

\section{Details of Crystallographic Studies}

$[\mathrm{Al}(\mathrm{OH}) 3,5 \mathrm{pydc}] \cdot 3.7 \mathrm{H}_{2} \mathrm{O}\left(1-\mathrm{H}_{2} \mathrm{O}\right)$ and $[\mathrm{Al}(\mathrm{OH}) 3,5 \mathrm{pydc}](1)$ : Synchrotron powder X-ray diffraction data for both the hydrated $\left(\mathbf{1}-\mathbf{H}_{\mathbf{2}} \mathbf{O}\right)$ and desolvated forms of $\mathbf{1}$ were collected at beamline I11 at Diamond Light Source (Oxon., UK). A sample of hydrated CAU-10-pydc (1$\mathbf{H}_{2} \mathrm{O}$ ) was ground and loaded into a $0.5 \mathrm{~mm}$ quartz glass capillary tube. The sample was then mounted on an I11 gas cell, mounted on the diffractometer and connected to the I11 gas-handling system. ${ }^{[29]}$ Data were collected at a wavelength of $\lambda=0.826952 \AA$ using the Position Sensitive Detector (PSD) over the range $0-90^{\circ} 2 \theta$ with a step size of $0.004^{\circ}$ in two steps $\left(\delta=2.00^{\circ}\right.$ and $\left.\delta=2.25^{\circ}\right)$ to allow for the gaps between detector modules; these scans were merged as part of the data acquisition. Data for the dehydrated form of $\mathbf{1}$ were collected using the same procedure on the same sample after heating to $150{ }^{\circ} \mathrm{C}$ under vacuum for $1 \mathrm{~h}$.

Data were cut off above $40^{\circ} 2 \theta$ as above this diffraction angle peak intensities were too low to distinguish from the background. Data for the desolvated form of CAU-10-pydc, 1, were analyzed first. Data were indexed, using the routines available in TOPAS-Academic, ${ }^{[30]}$ in the tetragonal space group $14_{1}$ /amd and LeBail fitted to give a cell $a$ $=21.5064(3) \AA, c=10.51189(16) \AA$. As this is the same symmetry as CAU-10- $\mathrm{CH}_{3},{ }^{[10]}$ a model for $\mathbf{1}$ was built by replacing 5-methylisophthalate linkers with 3,5-pyridinedicarboxylate units and geometry optimizing the resulting structure in the refined cell, using the Forcite routine of Materials Studio. ${ }^{[31]}$ The resulting structure was refined by the Rietveld method using TOPAS-Academic. Final refinement parameters are given in Table 1 and a Rietveld plot is shown in Figure $3 \mathrm{a}$ (see Supporting Information for complete list of refinement parameters).

For the hydrated form of CAU-10, $\mathbf{1}-\mathbf{H}_{\mathbf{2}} \mathbf{O}$, indexing gave a cell in the space group $I 4_{1} m d$ with LeBail fitted lattice parameters $a=$ 21.3963(2) Å, $c=10.67424(12) \AA$. The symmetry of desolvated 1 was lowered using the program POWDER CELL, ${ }^{[32]}$ and the resulting structure geometry optimized using the Forcite routine of Materials Studio. $\mathrm{H}_{2} \mathrm{O}$ molecules were located within the pores of the resulting model by Fourier difference maps as a final step in series of Rietveld refinement cycles, performed using TOPAS-Academic V.6. The occupancies and positions of each molecule were allowed to refine freely. Finally eight symmetry independent water molecules were identified, three of which are fully occupied. Details of the final refinement parameters are given in Table 1 and a Rietveld plot is shown in Figure 3b (see Supporting Information for complete list of refinement parameters).

[Al(2,6pydc) $\left.(\boldsymbol{\mu}-\mathrm{OH})\left(\mathrm{H}_{2} \mathrm{O}\right)\right]_{2}$ (2): Single crystal X-ray diffraction data were measured at beamline I19 at Diamond Light Source (Oxon., UK). A crystal was selected and mounted on an imide loop and placed on the diffractometer before being cooled to $80 \mathrm{~K}$. Data were collected using a Pilatus $300 \mathrm{~K}$ detector at a wavelength of $\lambda=0.6889 \AA$. Data were reduced using the CrysAlisPRO software. ${ }^{[33]}$ Systematic absences were consistent with a monoclinic unit cell $[a=7.1605(2) \AA$, $b=10.7407(5) \AA, c=10.8433(4) \AA, \beta=96.975(3)^{\circ}$; space group: I2/ $m$ ], however it was noticed that a number of satellite peaks were present in the data, possibly indicating a modulated structure. The frames were integrated although this gave a high $R_{\mathrm{Int}}\left(R_{\mathrm{Int}}=6.06 \%\right)$ - attributed in part to the satellite peaks. The structure was solved and refined using the routines available in the SHELX suite, within OLEX2, ${ }^{34,35]}$ but with relatively large final $R$ factors $\left(R_{1}=7.07 \%\right.$ and $w R_{2}=$
$18.93 \%)$. Moreover in the final structure (see Supporting Information), the thermal ellipsoids of the Al1, O1 and $\mathrm{O} 3$ sites have a strongly prolate shape, indicating a distribution of atomic positions and hinting at the nature of the modulation present in the structure.

To more accurately determine the structure, room temperature synchrotron powder X-ray diffraction data were collected at beamline I11 (Diamond Light Source, Oxon. UK) using the multi-analyzer crystal detector. ${ }^{[36]}$ Data were collected over the range $0-150^{\circ} 2 \theta$ with wavelength $\lambda=0.8260285 \AA$. Data were cut off above $65^{\circ} 2 \theta$ as the intensity of the diffraction peaks became difficult to distinguish from the background. Data were successfully indexed in the triclinic space group $P \overline{1}[a=8.12758(9) \AA, b=7.19259(4) \AA, c=8.12851(7) \AA, a=$ $\left.69.2738(6)^{\circ}, \beta=82.4838(4)^{\circ}, \gamma=69.2461(6)^{\circ}\right]$ using TOPAS-Academic $^{[30]}$. This triclinic cell is related to the $I 2 / m$ cell from single crystal diffraction by a simple transformation, which removes the centering and reduces the cell volume by half. The structure obtained from single crystal diffraction was thus transformed using PLATON ${ }^{[37]}$ and successfully refined by the Rietveld method using TOPAS-Academic. Errors on the isotropic displacement parameters were found to be noticeably large in the final refinement and when the final structure was tested for missing symmetry, using the ADDSYM routine of PLATON, a new monoclinic cell in the space group $I 2 / \mathrm{m}$ was suggested $[a=$ 7.19193(4) $\AA, \quad b=10.71549(6) \AA, \quad c=10.87754(6) \AA, \quad \beta=$ $97.5836(4)^{\circ}$ ], which is very similar to the cell found from the single crystal study. The structure was transformed into this new cell and rerefined by the Rietveld method. The final refinement gave a fit of $R_{\mathrm{wp}}$ $=9.62 \%\left(\chi^{2}=9.672\right)$. In the final refinement all peaks are fitted (i.e. no satellite peaks were observed); the slightly high values of the $R$ factor is typical for the refinement of MAC data on a coordination polymer. Final refinement parameters are given in Table 1 and a Rietveld plot is shown in Figure 3c (see Supporting Information for complete list of refinement parameters).

Crystallographic data (excluding structure factors) for the structures in this paper have been deposited with the Cambridge Crystallographic Data Centre, CCDC, 12 Union Road, Cambridge CB2 1EZ, UK. Copies of the data can be obtained free of charge on quoting the depository numbers CCDC-1861790 (1), CCDC-1861789 (1-H $\mathbf{2} \mathbf{O})$, and CCDC-1861788 (2) (Fax: +44-1223-336-033; E-Mail: deposit@ccdc.cam.ac.uk, http://www.ccdc.cam.ac.uk).

All figures and pictures by the authors are under a CC-BY4.0 license (https://creativecommons.org/licenses/by/4.0/)

Supporting Information (see footnote on the first page of this article): Thermogravimetric and elemental analyses, IR spectroscopy, summary of crystallographic results (including systematic absence comparisons, Rietveld plots, single crystal diffraction study) and Pore Size Distribution plots.

\section{Acknowledgements}

The authors wish to thank Diamond Light Source for allocation of beamtime at I11 (EE9225), with thanks also to C. A. Murray for additional measurements. M. R. Warren and J. Christensen (I19, Diamond Light Source) are also thanked for collection and assistance in interpreting single crystal diffraction data. $M T W$ wishes to acknowledge Deutsches Elektronen-Synchrotron (DESY) and Diamond Light Source for assistance with funding during writing of this paper. 
Keywords: Metal-organic frameworks; Synchrotron powder X-ray diffraction; Aluminum; Aluminum MOFs; Water sorption; High-throughput synthesis

\section{References}

[1] R. G. AbdulHalim, P. M. Bhatt, Y. Belmabkhout, A. Shkurenko, K. Adil, L. J. Barbour, M. Eddaoudi, J. Am. Chem. Soc. 2017, 139, 10715-10722.

[2] Y.-K. Seo, J. W. Yoon, J. S. Lee, Y. K. Hwang, C.-H. Jun, J.-S. Chang, S. Wuttke, P. Bazin, A. Vimont, M. Daturi, et al., Adv. Mater. 2012, 24, 806-810.

[3] H. Kim, S. Yang, S. R. Rao, S. Narayanan, E. A. Kapustin, H. Furukawa, A. S. Umans, O. M. Yaghi, E. N. Wang, Science 2017, $356,430$.

[4] J. J. Low, A. I. Benin, P. Jakubczak, J. F. Abrahamian, S. A. Faheem, R. R. Willis, J. Am. Chem. Soc. 2009, 131, 1583415842.

[5] T. Devic, C. Serre, Chem. Soc. Rev. 2014, 43, 6097-6115.

[6] M. Gaab, N. Trukhan, S. Maurer, R. Gummaraju, U. Müller, Microporous Mesoporous Mater. 2012, 157, 131-136.

[7] E. Alvarez, N. Guillou, C. Martineau, B. Bueken, B. Van de Voorde, C. Le Guillouzer, P. Fabry, F. Nouar, F. Taulelle, D. de Vos, et al., Angew. Chem. Int. Ed. 2015, 54, 3664-3668.

[8] F. Millange, C. Serre, G. Ferey, Chem. Commun. 2002, 822-823.

[9] T. Loiseau, C. Serre, C. Huguenard, G. Fink, F. Taulelle, M. Henry, T. Bataille, G. Férey, Chem. Eur. J. 2004, 10, 1373-1382.

[10] H. Reinsch, M. A. van der Veen, B. Gil, B. Marszalek, T. Verbiest, D. de Vos, N. Stock, Chem. Mater. 2012, 24, 17-26.

[11] D. Frohlich, E. Pantatosaki, P. D. Kolokathis, K. Markey, H. Reinsch, M. Baumgartner, M. A. van der Veen, D. E. De Vos, N. Stock, G. K. Papadopoulos, et al., J. Mater. Chem. A 2016, 4, 11859-11869.

[12] A. Cadiau, J. S. Lee, D. Damasceno Borges, P. Fabry, T. Devic, M. T. Wharmby, C. Martineau, D. Foucher, F. Taulelle, C.-H. Jun, et al., Adv. Mater. 2015, 27, 4775-4780.

[13] M. Wahiduzzaman, D. Lenzen, G. Maurin, N. Stock, M. T. Wharmby, Eur. J. Inorg. Chem. 2018, 3626-3632.

[14] O. M. Yaghi, M. O'Keeffe, N. W. Ockwig, H. K. Chae, M. Eddaoudi, J. Kim, Nature 2003, 423, 705-714.

[15] G. Férey, J. Solid State Chem. 2000, 152, 37-48.
[16] I. Senkovska, F. Hoffmann, M. Fröba, J. Getzschmann, W. Böhlmann, S. Kaskel, Microporous Mesoporous Mater. 2009, 122, 93-98.

[17] M. Lammert, M. T. Wharmby, S. Smolders, B. Bueken, A. Lieb, K. A. Lomachenko, D. D. Vos, N. Stock, Chem. Commun. 2015, $51,12578-12581$.

[18] Y. Cao, Z. Zhu, J. Xu, L. Wang, J. Sun, X. Chen, Y. Fan, Dalton Trans. 2015, 44, 1942-1947.

[19] M. T. Wharmby, M. Snoyek, T. Rhauderwiek, K. Ritter, N. Stock, Cryst. Growth Des. 2014, 14, 5310-5317.

[20] N. Stock, Microporous Mesoporous Mater. 2010, 129, 287-295.

[21] L. Sarkisov, A. Harrison, Mol. Simulat. 2011, 37, 1248-1257.

[22] C.-C. Ou, W. J. Borowski, J. A. Potenza, H. J. Schugar, Acta Crystallogr., Sect. B 1977, 33, 3246-3248.

[23] H. X. Liu, Q. H. Zhang, Z. X. Yu, X. P. Zhang, Y. Xu, Q. H. Fan, T. T. Huang, Adv. Mater. Res. 2013, 785-786, 428-431.

[24] A. J. Downs, H.-J. Himmel, in The Group 13 Metals Aluminum, Gallium, Indium, and Thallium: Chemical Patterns and Peculiarities (Eds.: S. Aldridge, A. J. Downs), John Wiley \& Sons, Ltd., 2011, pp. 1-74.

[25] P. Rubini, A. Lakatos, D. Champmartin, T. Kiss, Coord. Chem. Rev. 2002, 228, 137-152.

[26] N. Hermer, M. T. Wharmby, N. Stock, Z. Anorg. Allg. Chem. 2017, 643, 137-140.

[27] F. Rouquerol, J. Rouquerol, K. S. W. Sing, Adsorption by Powders and Porous Solids: Principles, Methodology and Applications, Academic Press, 1998.

[28] A. K. Rappe, C. J. Casewit, K. S. Colwell, W. A. Goddard, W. M. Skiff, J. Am. Chem. Soc. 1992, 114, 10024-10035.

[29] J. E. Parker, J. Potter, S. P. Thompson, A. R. Lennie, C. C. Tang, Mater. Sci. Forum 2012, 706-709, 1707-1712.

[30] A. Coelho, J. Appl. Crystallogr. 2018, 51, 210-218.

[31] Materials Studio v5.0, Accelrys, San Diego, USA; Cambridge, UK; Tokyo Japan, 2009.

[32] W. Kraus, G. Nolze, J. Appl. Crystallogr. 1996, 29, 301-303.

[33] Rigaku Oxford Diffraction, Agilent, CrysAlis PRO, Rigaku Oxford Diffraction, Yarnton, Oxfordshire, England, 2014.

[34] O. V. Dolomanov, L. J. Bourhis, R. J. Gildea, J. A. K. Howard, H. Puschmann, J. Appl. Crystallogr. 2009, 42, 339-341.

[35] G. Sheldrick, Acta Crystallogr., Sect. A 2008, 64, 112-122.

[36] S. P. Thompson, J. E. Parker, J. Potter, T. P. Hill, A. Birt, T. M. Cobb, F. Yuan, C. C. Tang, Rev. Sci. Instrum. 2009, 80, 0751070751079 .

[37] A. Spek, J. Appl. Crystallogr. 2003, 36, 7-13.

Received: August 14, 2018

Published online: November 19, 2018 